\title{
THE REGULATION AND PROTECTION OF CHILDREN'S RIGHTS IN KOSOVO FROM A LEGAL ASPECT
}

Summary: $\quad$ Children is the most delicate and important category of a family and its future and as well as for the society in general. Therefore, the state with its mechanisms are obliged to take care in creating conditions for their upbringing and welfare by looking after the best interest of the child.

In Kosovo, children and young people account for 60 per cent of the population. ${ }^{1}$ Therefore, it is of crucial importance to invest in the protection and promotion of their rights, regardless of whether they are in conflict or only in contact with the law. Thus, the legislation needs to be reformed and harmonised with best international standards and practices, which is also currently happening in Kosovo.

Keywords: $\quad$ children, family, protection, justice for juvenile and children, alternative measures and diversity, children under the age of criminal responsibility, child victims and witnesses

Every child is sacred. They are all God's creatures. If you do not want it, give it to me.

Mother Teresa

\footnotetext{
Bedri Bahtiri, PhD, Assistant Professor, Faculty of Law, University of Pristina, Kosovo Rr. Agim Ramadani, p.n. 10000 Prishtinë, Kosovo. Email address: bedri.bahtiri@uni-pr.edu. ORCID: https://orcid.org/0000-0002-8216-808X.

** Islam Querimi, PhD, Assistant Professor, Universiteti i Mitrovicës “Isa Boletini”, Fakulteti Juridik, Rr. Ukishin Kovaçica, 40000 Mitrovicë, Republika e Kosovës. Email address: i-qerimi@hotmail.com. ORCID: https://orcid.org/0000-0002-1645-079X.

1 Legal Framework for Children's Rights in Kosovo: Study on Compliance of Legislation in force with the Convention on the Rights of the Child/ UNICEF, Pristina, 2014, p. 5.
} 


\section{INTRODUCTION}

This year, $2019,{ }^{2}$ marks the $30^{\text {th }}$ anniversary of the Convention on the Rights of the Child (CRC), a landmark convention that constitutes one of the six core human rights treaties. With near universal ratification, the Convention establishes the fundamental rights of children and young people, the roles and responsibilities of rights-holders and duty bearers aiming at promoting, protecting and realizing children's rights. With the youngest population in Europe, it is particularly significant for Kosovo Government to be working with the various stakeholders on the realization of the rights of children and youth as enshrined in the Convention, its Optional Protocols, and several other international and regional human rights instruments.

The Constitution of Kosovo (see article 50, paragraphs 1-5) recognizes the Convention on the Rights of the Child and its optional protocols, as part of its internal legislation by giving it an obligatory status for implementation. Beside this, Kosovo legislative framework draws on various international and regional standards, reflecting a commitment to the realization of the rights of children and young people.

Kosovo, like other democratic countries that are in the integration processes to become part of Europe and other international organizations, is obliged to harmonize its legislation with the EU legislation and the international legal instruments of the Council of Europe.

In positive law, assessing the child's best interest and making decisions accordingly is an important and mandatory issue for all institutions dealing with juveniles and children. This is a great challenge faced not only by the justice institutions in Kosovo but also beyond.

Since the 1960s in North America and across Europe, the criminal policy trends for juveniles have brought the urgency based on the actions of the subsidiarity principle and proportionality of state interventions against juvenile offenders, and which are then included in all international human rights standards. ${ }^{3}$

Actually, Kosovo is drafting a new Child Protection Law which intends to protect the child by completing the legal and institutional framework for the implementation of the Constitution of the Republic of Kosovo and the United Nations Convention on the Rights of the Child. ${ }^{4}$ Beside the Child Protection in Republic of Kosovo, there are different legislation that provides services and protection for children: Law on Family number (2004/32), Law on Family and Social Services number (Nr. 02/L-17) and Law on Amending and Supplementing the Law on Family and Social Services Number (Nr. 04/L-081) Law on Prevention and Combating Trafficking with Human Beings numbers (Nr. 04/L-218), Law on Protection Against Domestic Violence Number (Nr. 03/L-182) Law on Social Assistance Scheme Number (Nr.2003/15), Law on Material Assistance for the Family of Persons with Disabilities Number (Nr.03/L-02), Law on Preschool Education Number (Nr.02/L-53), Law on Health Number (Nr.04/L-125), Labor Law

2 Adopted and opened for signature, ratification and accession by General Assembly resolution 44/25 of 20 November 1989. Entry into force 2 September 1990, in accordance with article 49.

3 J. Junger Tas and F. Dünkel, Reforming Juvenile Justice, Springer, 2009, p. 147.

4 http://ligjet.kuvendikosoves.org/LTS/DraftLawPhase?languageid=2\&draftLawId=106. Website clicked on 11. 3. 2019. 
Number (Nr.03/L-212) Penal Code Number (Nr.04/L-082), Penal Procedural Code Number (Nr.04/L-123), Juvenile Justice Code Number (Nr.03/L-193). ${ }^{5}$

Although looking at the legal regulation of most states concerning rights of children, they are well founded and in line with international standards. However, good drafted legislation needs also to be implemented and in this regard many states fail. Concerning the situation in Kosovo, a study has been conducted by UNICEF-EU in Kosovo and has confirmed that 'The legislation on many issues is largely in harmony with international standards. ${ }^{6}$

A child's development should be supported and encouraged in its path towards independence and responsibility. In addition, there are many legal acts and decisions regulating the responsibility of various public authority institutions for preventing violence against children, ensuring their well-being and adequate health protection. Therefore, this paper has as its main objective to reflect the legal aspect of children's rights in Kosovo, legal loopholes, legal collision, and current trends in the practice of establishing, protecting and promoting children's rights and the current reform in this field in Kosovo.

To carry out a development analysis on children's rights in Kosovo, first the relevant research questions will be asked, which should be answered in the context of this work as follows:

1. What is the state of legislative regulation in the Republic of Kosovo in the field of children's rights protection?

2. What are the means of child protection in Kosovo?

3. What are the recent reforms that have been made to the Juvenile Justice Code in Kosovo?

4. What was the situation before and what will be the solution to the problem of treatment of children who have committed crimes under the age of criminal responsibility (under 14)?

5. With what examples - statistical data, can the views of the authors of this paper be supported in terms of means of child protection in Kosovo?

\section{THE LEGAL SITUATION IN THE REPUBLIC OF KOSOVO}

The legal basis that regulates the protection of children's rights in the Republic of Kosovo is its Constitution but also directly applicable international legal instruments in accordance with Article 22 of the Constitution of Kosovo. ${ }^{7}$ Progress have also been noted through the adoption of the concept in the institutional set up plan with the establishment of the Council for Prote-

5 Kuvendi i Republikës së Kosovës, Hulumtim Parlamentar 'Analizë mbi Mbrojtjen e Fëmijëve' June 2018. Përgatitur për Komisionin për të Drejtat e Njeriut, Barazi Gjinore, për Persona të Pagjetur dhe Peticione (translation from Albanian Version).

6 The Legal Framework for Child Rights in Kosovo 'A study of the compatibility of existing legislation with the Convention on the Rights of the Child' Published by UNICEF and EU in 2014.

7 This article stipulates that: "The human rights and freedoms guaranteed by the international agreements and instruments enshrined in this Constitution are directly enforced in the Republic of Kosovo and have priority in the event of conflict, against provisions of laws and other acts of public institutions: (1) the Universal Declaration of Human Rights, (2) the European Convention for the Protection of Human Rights and Fundamental Freedoms and its Protocols, (3) the International Convention on Civil and Political Rights and its Protocols, (4) Council of Europe Framework Convention for the Protection of National Minorities, (5) Convention on the Elimination of All Forms of Racial Discrimination, (6) Convention on the Elimination of All 
ction and Justice for Children, at the Government of the Republic of Kosovo (established on August 25, 2011).

European Union member states ${ }^{8}$ and other European countries regulate this issue in various ways, promote and protect the rights of children through the special legislation on children's rights, through the ombudsman for children or through comprehensive laws for promotion of children's rights and their protection.

The promotion of children's rights and protection of children is within the competence of all levels of power and public institutions, local self-government and social care bodies in any country that provides child and family protection services. The task of these social institutions is to provide children with the protection of their rights in the field of education, physical, mental, emotional and moral development.

For protecting the children, severe penalties for sexual abuse of persons under the age of 16 (Article 235 of the Criminal Code of Kosovo) are foreseen, regardless of whether the child consents to it or not. ${ }^{9}$ The jurisprudence of the Court has found guilty an adult person for having sex with the consent of the girl because she was under the age of $16 .^{10}$

Child protection laws mainly prohibit humiliation of the child, intimidation or punishment in any way that inflicts a bodily harm on the child, or if the physical or mental health is endangered. ${ }^{11}$ Similar provisions are also found in basic laws for primary ${ }^{12}$ and secondary schools which oblige schools to implement all necessary measures to prevent physical and psychological violence. Parental Relationships and Child Welfare are complementary regulated by such laws and foresee that children should be treated with conscience, responsibility and nobility. ${ }^{13}$ The child must not be insulted, punished physically or other means. ${ }^{14}$ This in many countries, including Kosovo, is not always respected.

Historically viewed, the Roman legal system as one of the most important historical systems of ancient times, initially did not recognise parental responsibility as an overall set of legal rules. The father and the mother were not equally authorised and equally obliged to take care of the upbringing and education of their children. ${ }^{15}$ However, this situation changed in later periods of Roman society development.

Also, in Kosovo, from a historical perspective, depending on the degree of economic and social development, parental relations and children's rights have gone through various stages

Forms of Discrimination against Women, (7) Convention on the Rights of the Child, (8) Convention against Torture and Other Cruel, Inhuman or Degrading Treatment or Punishment."

8 European Center for Parliamentary Research and Documentation (European Centre for Parliamentary Research and Documentation: Request 1407 - Violence against children, by the National Assembly of the Republic of Serbia, Request 866 Billon Youth (Children), by Slovak National Council). Judgment of the District Court in Gjilan, P. No. 97/65. paragraph 2.

13 Law No. 03/L-182 on the protection from violence in family, Article 1.

14 For more see: Research on the topic "Violence in school", KIPRED, 2013, pg. 3. 
of progress, where a very important factor in the development of these relations is the tradition. It is worth mentioning that in the Albanian customary law regulation and protection of children's rights was enshrined in all Albanian canons. ${ }^{16}$ Their rights were determined by the norms of criminal law and civil law.

Also, according to the Albanian customary law, children under 15 years of age were not subject to the practice of criminal violence, such as revenge and blood feuds. Such an action was considered a cowardly act and the society would forever scorn and despise the perpetrator of this crime. According to the Law on Obligation, the responsibility falls directly upon the adult male members of their families (N 672 Kanun of Lekë Dukagjini). They were also not subject to the oath procedure (N 835 Kanun of Lekë Dukagjini).

In the past, it was thought that the poor level of the society, unemployed people, sick people, minorities, foreigners and other marginalized groups of the population are more vulnerable to becoming victims of crime. However, the new form of criminality such as organized crime, human trafficking, terrorist activities etc. do not choose certain level of society but involve and endanger the whole society. ${ }^{17}$

What the court or other administrative body must consider deciding where the child's interest is primarily dealt with is that the court or other competent administrative body should assess the physical, emotional, educational and the health needs of the child.

These obligations for the protection of children's rights derive from international acts adopted by various international organizations dealing with the protection of human rights in general and the rights of children, as well as the legal infrastructure adopted from the state of Kosovo itself.

Given all the above, the legislation on the protection of children's rights in Kosovo will be compared through comparative analysis with international standards for the protection of children's rights, with the Convention on Children's Rights. Consequently, the best practices for the protection of children's rights and the active role that court, and other bodies should have in cases where children are part of the procedures will be highlighted.

\subsection{CONSTITUTION OF THE REPUBLIC OF KOSOVO}

The Constitution of the Republic of Kosovo, among other things, foresees the Convention on Children's Rights as directly applicable.

The international instruments are based on the principle of the best interest for the child and so is the Constitution of the Republic of Kosovo. Article 50 paragraph 4 provides that "all actions undertaken by public or private authorities dealing with children shall be in the best interest of the child". In addition, Article 50 paragraph 5 foresees that every child has the right to "regular relationships and direct contact" with their parents, unless a competent body has decided that this would not be in the best interest of the child.

16 I. Qerimi, Gewohnheitsrecht in Albanien: Rolle und Herkunft des Kann. Uberblick uber den Kanun bei den Albanern, Munich, 2010 , p. 31. 
The Constitution of Kosovo in Article 50 defines the rights of the child. Children are entitled to protection and care necessary for their wellbeing. The Constitution equates children born out of wedlock with those born in wedlock in terms of their rights. Children enjoy protection from violence, abuse and exploitation. In matters relating to children, all public and private institutions are obliged to prioritize the best interest of the child.

The most frequent cases of child abuse are physical, psychological, sexual abuse, exploitation of severe physical labor and recruitment of children in armed formations or in groups and terrorist organizations. ${ }^{18}$

\subsection{FAMILY LAW OF KOSOVO}

As in every other country, in Kosovo too, tradition and customs have had an undisputed influence. The regulation of family in Kosovo began to be institutionalized after the Second World War, when for the first-time family and parental relationships was regulated by the Basic Marriage Law of 13 April 1946, which was implemented in the entire territory of the former Federal People's Republic of Yugoslavia. ${ }^{19}$

Until the adoption of the new law, which is now in effect, family relations, and those between parents and children are regulated by the Law on Marriage and Family Relations of $1984 .^{20}$

The applicable Family Law of Kosovo $(\mathrm{FLK})^{21}$ regulates family affairs, including the relationship between parents and children, adoption, maintenance, custody, protection of children without parental care, parent's contact with the child when the parental right is not exercised etc. ${ }^{22}$

The regulation of these relations is based also on the principles of the protection of children's rights and the responsibility of both parents to raise and educate their children. Furthermore, children born out of wedlock enjoy the same rights and the same obligations as children born in wedlock. FLK foresees parental responsibility for childcare and financial maintenance and food. Children up to the age of 18 are a parent's obligation to maintain financially and feed. Exceptionally, the Family Law (FLK) in Article 136 par. 2, as well as the Kosovo Law on Labour in Article 7 par. 2, allows for the possibility that children between the ages of fifteen (15) and eighteen (18) to gain wealth, ${ }^{23}$, and with these gains to contribute towards their well-being. Regarding the child's right to financial maintenance as a legal obligation of the parents while the child is a minor, some authors consider that after this time it is not right for the child to seek financial maintenance from the parents, if he or she has enough material resources.

18 R. Halili, p. 50-51.

19 H. Podvorica, E Drejta Familjare, Pristina, 2011, p. 21.

20 Law on Marriage and Family Relations, Official Gazette of SAPK no. 10/84, date 28 March 1984.

21 Family Law of Kosovo (Law No. 2004/32) - The Basic Law on Family is the Kosovo Family Law (Law No. 2004/32). It was adopted by the Assembly of Kosovo in February 2006, and was promulgated by the Special Representative of the Secretary-General with UNMIK / REG / 2006/7. 
The active role of courts and other competent bodies in investigating, reviewing and providing legal protection for the rights of children in all legal proceedings, including the period of the divorce proceedings which also refers to the duty of the court to ex officio appoint an interim measure within the meaning of the provisions of Articles 225, 327 and 328 of the FLK. ${ }^{24}$ During divorce proceedings, besides the court, an essential role in protection of children's rights, not only in a formal but also in a substantial connotation, has also the Custodian Body.

With the provision of Article 138 of the FLK, is foreseen the exercise of care by the Custodian Body. According to this provision it is foreseen that the Custodian Body decides on behalf of the child's interests only at the request of one or both parents, or at the request of a third person, in cases where the child is under that person's supervision or else by the court's decision.

The Family Law in Article 6 stipulates that the body responsible for the institutional protection of the child's rights is the Custodian Body. This body has a special role in protecting the rights of children without parental care (custody, foster care, residential housing and adoption), who are entitled to special social protection. In this regard, Article 158 of the FLK stipulates that the decision on the implementation of any mode of protection of children without parental care is taken after a detailed examination of each case individually, while the competent body will draw a conclusion on the manner of protection for the family that meets the child's requirements to a large extent. It is worth mentioning that in recent years much has been done in the field of child protection, but a big challenge remains the implementation of legislation, which is often due to the lack of enough budgetary means.

\subsection{LAW ON SOCIAL AND FAMILY SERVICES}

The Law on Social and Family Services (with its amendments), in Article 7, among other things, determines the role of Centers for Social Work (CSWs) and the obligation of the latter to establish the Custodian Body. ${ }^{25}$ This law also defines the obligations of the CSWs, respectively the Custodian Body, regarding the services they should provide for children without parental care. Article 9, paragraph 1, of this law emphasizes the obligation of these institutions that in all matters related to the provision of services for children and families, the first and most important consideration should be the best interest of the child.

This law regulates the provision of social and family services to persons in need and families who need assistance and services. In the group of persons in need according to this law are also included children such as children without parental care. An important role according to this law has also the Department of Social Welfare, which functions within the Ministry of Labour and Social Welfare. This Department, among other things, is responsible for issuing instructions regarding the filing of requests for custody orders before the Courts that have to do with endangered children and adults and establishing and coordinating the panel for placement of children in foster care or for adoption.

24 FLK contains material provisions and procedural provisions, which regulate the field of Family Law.

25 See Law on Social and Family Services, Law no. 02/L-17, Article 7 par. 2. 


\subsubsection{ROLE OF CSWS}

CSWs have an important role in cases where children's rights are affected and to take measures and actions to protect children's rights. Within each municipality, are established CSWs and they exist as competent bodies for providing social and family services to persons in need of social care, counselling and material assistance for people in need. Within the CSWs, also a Custodian Body is established to perform the duties as defined by the respective laws of Kosovo. CSWs is obliged to make professional assessments for each person or family living or located in its territory seeking assistance from it or in some other form deemed in need for social and family services. These CSWs also provides services for children and families and in its work, priority should be given to the best interest of the child. The CSWs provides social care when a child needs social services because it is without parental care or its parents are unable to provide an adequate level of care due to inability or illness, psycho-social problems or any other reason. They also maintain a register of families and children in need who live in its territory. In cases where the Court notifies the CSW on procedures regarding a child and that child is known for this CSW, the latter is obliged to provide the Court with any information or advice relevant to case management.

\subsection{JUVENILE JUSTICE CODE}

The Juvenile Justice Code ${ }^{26}$ is very important in the corpus of legislation of the Republic of Kosovo for the promotion and protection of children's rights in Kosovo. This Juvenile Justice Code has been approved by the Assembly of Kosovo and is highly appraised by international and local experts. ${ }^{27}$

The drafting of amendments to the Juvenile Justice Code was preceded by detailed analyses provided by local and international experts as well as judicial practice, where the depth of these analyses affects a considerable number of applicable laws in the Republic of Kosovo. ${ }^{28}$

\subsubsection{REASONING FOR AMENDING AND SUPPLEMENTING THE JUVENILE JUSTICE CODE}

During the 15 years of implementation of the Juvenile Justice Code, since its entry into force in year $2004^{29}$ and the amended version in year 2010, ${ }^{30}$ certain legal shortcomings and non-implementation of provisions are noted. In this respect, the category of children under the age for being criminally responsible and children victims and witnesses were not covered by the former Juvenile Justice Code. Moreover, the need for change and supplementation

26 Juvenile Justice Code no. 03/L-193, Official Gazette 78/2010.

27 The Juvenile Justice Code was drafted by a wide-ranging Working Group of the Ministry of Justice, where members were experts in the area of criminal justice for juveniles, the field of execution of criminal sanctions, of civil society in the field of children's rights protection, the Office of the Prime Minister, UNICEF, the Ombudsman and other public institutions. Rights of the Child/UNICEF, Pristina, 2014.

29 http://www.unmikonline.org/regulations/unmikgazette/03albanian/A2004regs/RA2004-08-JJC.pdf. 
came also as result of the increasing number of delinquencies among juveniles as well as children under the age of criminal responsibility. ${ }^{31}$

In this regard, the Ministry of Justice, by the end of 2016, for the third time undertook the legislative initiative to supplement and amend the Juvenile Justice Code. After a year of intense work by local and international experts in 2017, the Government of Kosovo approved the new Juvenile Justice Code at its regular meeting. The Juvenile Justice Code ${ }^{32}$ has now been approved and published in the official gazette of the Republic of Kosovo and was highly evaluated by MPs during the readings in the Assembly. ${ }^{33}$

The process of changes to the Juvenile Justice Code was preceded by reforms at the global, European and Kosovo level. In this respect it is worth mentioning some documents issued after 2010:

- Guidelines of the Council of Europe on child-friendly justice year 2010;34

- Tenth Commentary of the United Nations on the Rights of Children and Juvenile Justice; ${ }^{35}$

- The Progress Report of Kosovo of year 2014, where it is emphasized that "the Government must take into consideration the recommendations from the joint EU/UNICEF project on Juvenile Justice"; ${ }^{36}$

- UNICEF-EU Study in Kosovo "The Legal Framework for Children's Rights in Kosovo" year 2014. ${ }^{37}$ A study on the compatibility of the legislation in force with the Convention on the Rights of the Child;

- Acquis Communitaire, particularly with the recent directives that have been drawn specifically on the protection of children during the legal process. ${ }^{38}$

\subsubsection{Amendments and Supplement}

The new Juvenile Justice Code brings many changes that have as a purpose, the establishment and implementation of alternative ways in resolving criminal-legal disputes, and the direct avoidance of juvenile sanctioning, respectively of their institutional treatment. ${ }^{39}$

31 According to the annual report of the Division for Social Services, the number of delinquent children in 2017, assisted by the CSCs, is 603 children, while children with asocial behavior during 2017 were 148. In addition, the changes to the Juvenile Justice Code have also preceded the findings presented during the many workshops and trainings that have been held regarding the best practical implementation of the Code, involving Judges, Prosecutors, Police, representatives of Kosovo Chamber of Advocates, Centers for Social Work, Kosovo Correctional Service, Kosovo Probation Service, representatives from civil society, holding consultative meetings with the juvenile etc.

http://www.kryeministri-ks.net/?page=1,9,7050.

https://gzk.rks-gov.net/ActDetail.aspx?ActID=18019.

https://www.coe.int/en/web/children/child-friendly-justice.

http://www.ohchr.org/english/bodies/crc/docs/CRC.C.GC.10.pdf.

Kosovo Progress Report, European Commission published October 2014, faqe 18.

https://www.unicef.org/kosovoprogramme/Legal-FË-Shqip.pdf.

http://eur-lex.europa.eu/legal-content/EN/TXT/?uri=CELEX\%3A32016L0800.

I. Qerimi and B. Bahtiri, Alternative Sanktionen im kosovarischen Strafrechtssystem, Zeitschrift für die gesamte Strafrechtswissenschaft, vol. 128, no. 4, 2017, p. 1207-1226. 
Alternative measures, with special emphasis on diversity measures bring benefits to both juveniles, the community and society. It has been argued that diversity measures have an impact on lowering the expenses for the court, lowering the social control level exercised by the juvenile justice system and reducing stigmatization from entering the justice system. ${ }^{40}$

The minimum age of criminal liability indicates the age whereby the criminal justice system can commence a criminal procedure against a child who has committed a criminal offense. A child under the age of criminal responsibility is seen as "doli incapax" ${ }^{41}$

Thus, the most significant changes to current solutions are as follows:

i. The Code contains provisions that apply to juveniles as perpetrators of criminal offences pertaining to:

(i) material criminal law, criminal proceedings and the execution of criminal sanctions;

(ii) the provisions for the bodies that implement it; and

(ii) provisions for the criminal-legal protection of children and minors to the detriment of whom the offense was committed.

ii. "Best interest of the child", ${ }^{42}$ which is also one of the main principles foreseen in the Convention for Children Rights;

iii. Protection of children under the age of criminal responsibility;

The 14-year-old age set out in Kosovo's criminal law has made the category under this age to be perceived as irresponsible and, thus, undermined the consequences of failure to intervene in time and with proper mechanisms. This concern and debate have been translated into legal action through the incorporation of a special chapter ${ }^{43}$ that regulates the protection of children under the age of criminal responsibility.

iv. The right to privacy of juvenile offenders will be respected at all stages of the proceedings so that the media will not publish the juvenile's name or any other data that could reveal the identity;

v. Another novelty is reduction of the time limit for reaching a mediation agreement. Before it was 90 days and now it has been reduced to 30 days. ${ }^{44}$

vi. The duplication of diversity measures. ${ }^{45}$

vii. In coordination with the prosecutor, against a juvenile perpetrator may be imposed a police warning for criminal offenses for which a fine or prison sentence of up to three

40 Ed. by K. Heilbrun, N. E. Sevin Goldstein, and R. E. Redding, Juvenile Delinquency, Prevention, Assessment and Intervention, Oxford University Press, 2005, p. 162. 
years is foreseen, if they have not previously committed a criminal offense, or are not recidivist; ${ }^{46}$

viii. Also, has been regulated the manner of keeping records ${ }^{47}$ and it has been determined that the criminal record for the imposition of diversity measures and non-institutional educational measures do not have the character of criminal records in the sense of the Criminal Code and the Criminal Procedure Code of Kosovo;

ix. Also, to facilitate the understanding and the more correct interpretation of the provisions of the Juvenile Justice Code it has been defined what is meant with and when the deprivation of liberty is involved. This in the past has presented problems in practice $^{48}$

x. Legal deadlines have been fixed and shortened during the pre-trial phase. According to the Juvenile Justice Code, the pre-trial phase should be completed within six months, exceptionally up to 12 months.

xi. A special part of the Code is the protection of child victims and witnesses of crimes, ${ }^{49}$ with two chapters:

(i) Chapter I - Protection of the child victim of a criminal proceeding, and

(ii) Chapter II- Protection of Child Victims or Witnesses.

With the provisions of these two chapters, effort has been made to provide protection for child victims and witnesses in criminal proceedings.

In the past there was a world view about the value of the testimony, so that children were not recognized as witnesses in criminal proceedings. This world view has changed with new provisions in the legislation. However, special attention to the protection of children and their special treatment still exist. ${ }^{50}$

46 Article 20 paragraph 1.16 of the Juvenile Justice Code.

47 Article 21 paragraph 3 of the Juvenile Justice Code.

48 Article 3 paragraph 1.21 of the Juvenile Justice Code.

49 Child Victims and Witnesses are guaranteed a long list of rights and protection according to the following international standards, but not limited to:

- Trial of adults for acts committed against juveniles (Article 109);

- Investigating child-offenses by specialized police officers (Article 110);

- The best interest of the child and other recognized principles in the field of child protection (Articles 111 and 112);

- Proceedings foresee interrogation by professionals, with the support of psychologists and in special environments, and through technological equipment, with the presence of defenders, etc (Article 113);

- Protecting children by not allowing contact with the perpetrators (Article 117);

- Office for protection and assistance to victims (Article 118);

- Legal protection (Article 121);

- Protection measures and orders (Article 122);

- Language, interpreter and other special measures (Article 123);

- Medical examinations and taking samples from the body (Article 124);

- Support person from the Center for Social Work (Article 125);

- Reception facilities (Article 128);

- Equipment in the courtroom (Article 130);

- Right to Return and Compensation (Article 133); 
In this respect, according to the model of contemporary legislation, specific forms of interrogation of children and juveniles as victims of specific criminal offenses are foreseen. Also, here, is foreseen a specialization for children's mediators. ${ }^{51}$

The main purpose of the specific treatment of juvenile offenders is that the minor should be re-socialized through compensation for what has been released during his education. This is also justified by the fact that given their young age if adequate measures are taken, there is more hope for improvement, otherwise the society will have a great deal of damage. ${ }^{52}$

\subsubsection{CONCLUSION AND EXPECTATIONS}

The latest reformation of the Juvenile Justice System has reached a fairly high level and will largely fulfil the gaps identified during the years of its implementation in practice.

The innovations introduced and included in certain provisions are an added hope and guarantee that the position of minors and children as part of the legal process will be at another level. In this respect, it is excepted that they will have a free and fair trial, prompt trial and in his/her best interest, friendly and appropriate procedures, avoiding unnecessary court proceedings and potential stigmatization, greater family involvement, and the growing role of supportive institutions, specialization and increased responsibility of professionals, resocialization and programs based on education and enhancement of professional skills, sustainable integration in the family and society through employment and continuing education, inclusion in compensation and rehabilitation schemes.

\subsubsection{CHALLENGES AND THEIR REDUCTIONS THROUGH ADDRESSING THE PROBLEM}

- The issuing of the sub-legal acts within legal deadlines will assist the full implementation in practice of some parts of this Juvenile Justice Code;

- Effective implementation of these changes included in the Juvenile Justice Code are challenges that require an additional commitment from the institutions to continue with the specialization of professionals through adequate training for the implementation of legal provisions, proper budget planning and allocation, adequate space creation and recruitment of appropriate staffing, increased accountability and strengthening of inter-institutional coordination, creation of professional services, collection and management of data for the study of juvenile delinquency phenomena, as well as better policy planning and legislation development in the future in addition to problems that will be identified in judicial practice and other law enforcement mechanisms;

51 B. Bahtiri and I. Qerimi, Mediation as a Way of Alternative Resolution of Disputes in Kosovo, Iliria International Review, vol. 1, 2014, p. 291-322.

52 E. Sahiti, and R. Murati, E Dejta e Procedurës Penale, Botime Artini, Pristine, 2016, p. 445. It is worth mentioning that Albanians have regulated mediation very early by the customary Albanian law, summarized in the Kanun. For more information see B. Bahtiri and I. Qerimi, Vermittlung und Versöhnung als alte Phänomene unter Albanern, Die Wirtschaftsmediation-Fachmagzin für Unternehmen und öffentliche Verwaltung, vol. 4, 2014, p. 56-60. 
- The issuing of police warning will be a challenge for state organs to better implement it;

- A challenge is the increase of the powers of the guardianship body which, for the performance of its new duties, should increase its capacities as staff and adequate spaces for successful work, especially for the category of children under the age of 14;

- Supervision of Law Enforcement by the Parliamentary Commission on Legislation, as a functional committee responsible for overseeing the implementation of the laws in the field of justice as well as other functional committees.

\subsection{DRAFT LAW ON CHILD PROTECTION}

The Draft Law on Child Protection which is in the process of completing and amending the Parliamentary Committees of the Assembly, which is not finalized yet and we do not know exactly what will be the volume of amendments that will be made. However, this Draft Law aims to co-ordinate and deepen inter-institutional cooperation by further clarifying the role and responsibilities of all stakeholders in the best interests of children.

\section{MEANS OF PROTECTING CHILDREN}

Fulfilment of the best interests of the child occurs when the need for their physical and psychological development is met within the context of their biological family.

Kosovo as well as other countries is not immune when it comes to the violation of children's rights and their victimization starts from family through domestic violence, where the most common victims are children ${ }^{53}$ even if they are not the direct target of violence.

In practice, there are cases when children are left without parental care. According to the Family Law of Kosovo, children without parental care are those children whose parents are not alive, are unknown or have gone missing. Also, children without parental care are those children whose parents for whatever reason, temporarily or permanently fail to perform their parental duties or parental care. ${ }^{54}$ This category of children is entitled to social and state protection. Some of the main means of legal and family protection of children without parental care are custody, foster care, residential housing ${ }^{55}$ and adoption. This protection is achieved by providing conditions for the normal development of the child by making the best possible compensation for the loss of parents or parental care.

53 R. Halili, Viktimologjia, Pristine, 2011, p. 79.

54 FLK, Article 156.

55 In residential housing are placed 4 children with disabilities. The data was provided by Vebi Mujku, Director of the Centre for Social Care in Pristina, 26. 2. 2018. 


\subsection{CUSTODY}

The Family Law of Kosovo (FLK) in Article 6 stipulates that the body responsible for the institutional protection of children's rights is the Custodian Body. Custody is a family law institution, with the help of which the custodian, under the supervision of state bodies, assumes to take care of a child who is not under parental care. The purpose of custody is to ensure that children who are not in parental care are offered the necessary conditions for education, growth, schooling, as well as physical and mental development, so that they become a conscious citizen and able to protect their interests and rights. The custodian of the children is obliged to take good care of the child's personality, health and education. A child in custody who has not reached the age of 14 cannot exercise their legal affairs. ${ }^{56}$

The legal form of child protection, known as child custody, according to the official data of the CSWs in Pristina is assigned for 65 cases, including children without parental care, abused and neglected children, as well as children whose parents are prevented from performing their parental duties. ${ }^{57}$

\subsection{FOSTER CARE}

Children without parental care or neglected children are placed in another family so they are provided with the necessary conditions for their development, education and training for independent life and work. In these families are placed children neglected in education, as well as children with impeded developmental. This placement continues until they are enabled to live and work independently. Placement is possible in a family that has both parents as well as a family with only one parent. Placement in a family is done with the prior consent of the biological parents and that placement continues if the circumstances that have caused the placement to continue. Placement is done through the custodian body, which takes all necessary measures. Placement is done in a family that can successfully fulfil parental obligations such as education, care and schooling. Children without parental care in their family, placed in foster care, are altogether 50 and for each child is paid $€ 75$ a month, a total of $€ 45.000$ were paid in 2017. ${ }^{58}$ Alternative ways of child protection: Children without family, placed in foster care, according to official data of the CSW in Pristina, are 14 children, out of which 6 are disabled and 8 are healthy. For children with disabilities a sum of $€ 250$ per month is paid, which is paid to the foster family, while for the healthy children without parents placed in foster care a sum of $€ 150$ is paid. ${ }^{59}$

According to the data provided by the January-December 2017 Annual Report of the Division for Social Services, the Department of Social and Family Policy at the Ministry of Labour

\footnotetext{
56 FLK, Article 136.

57 Centre for Social Care in Pristina, database for professional social services, dt. 02/26/2018.

58 The data was provided by Vebi Mujku, Director of the CSW in Pristina, 26. 2. 2018. 
and Social Welfare, Abandoned Children, during 2017, 34 new cases of abandoned children were reported, with 8 of them potentially abandoned.

The following are graphs showing new cases of abandoned children by month (table 1) and by municipalities (table 2 ) reported by CSWs:

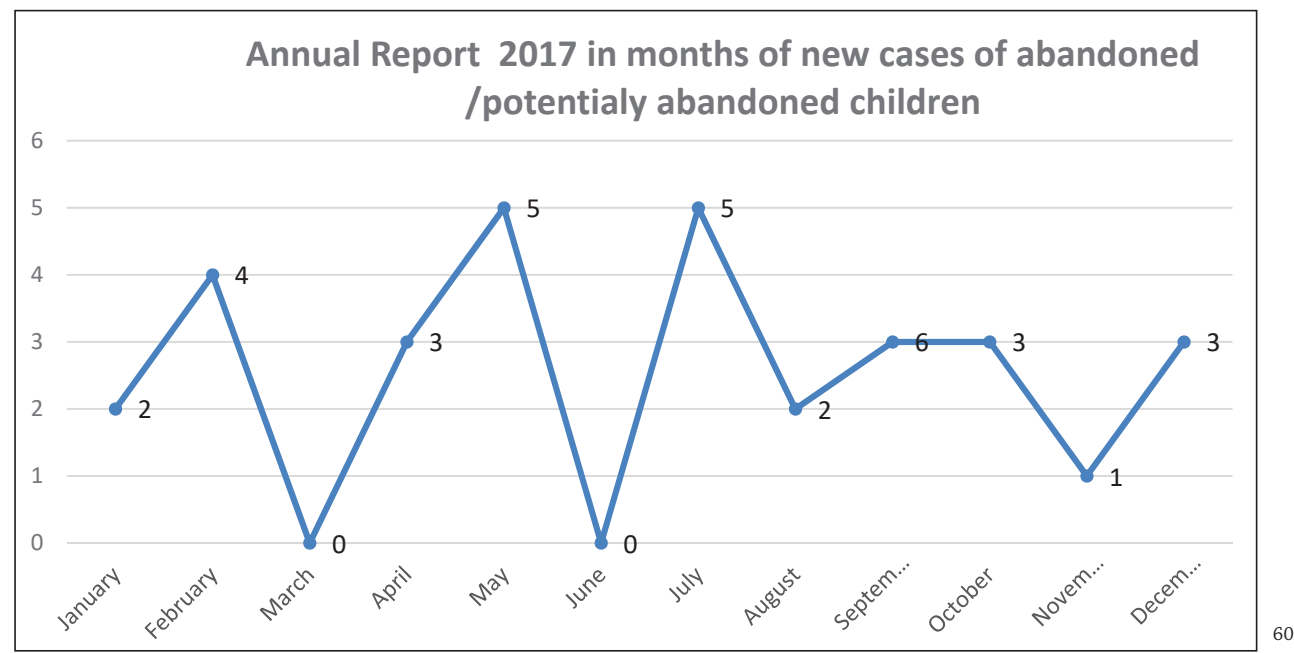

As can be seen in Table 1, annual reports are presented in months and new cases of abandoned children, where in the months of the summer season (April - August) there were more cases of abandonment of children in Kosovo.

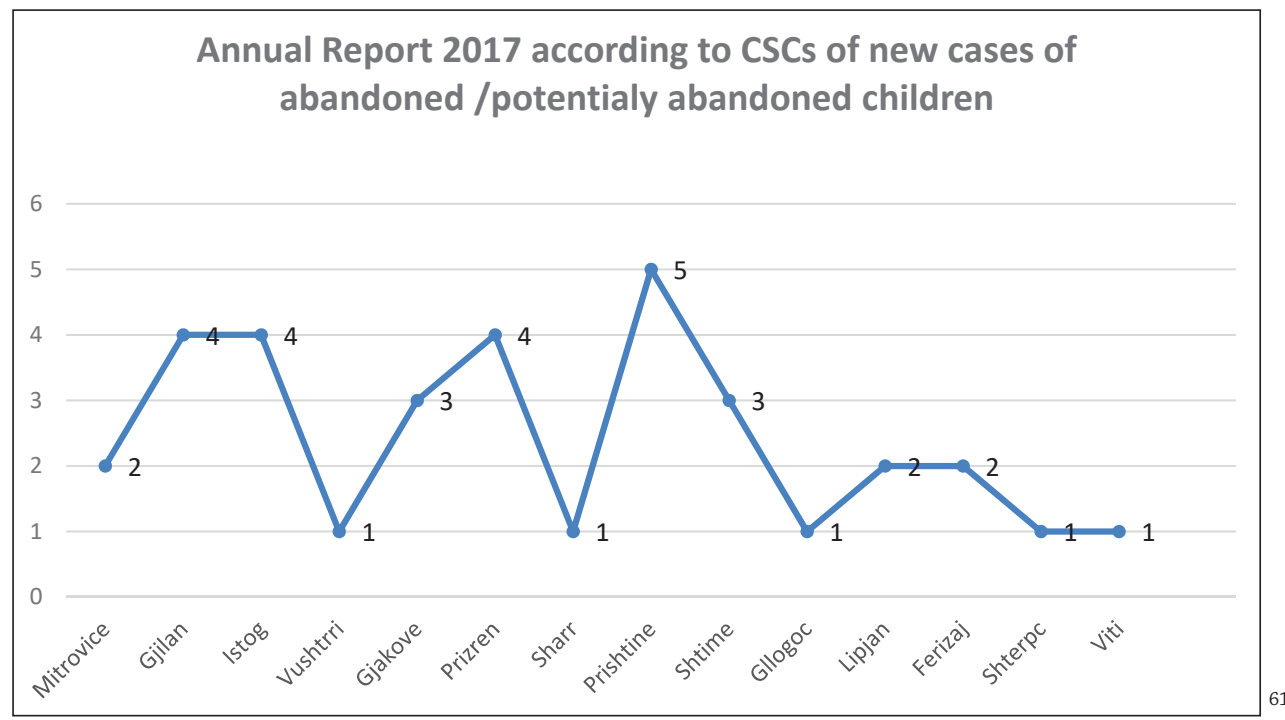

60 Table 1.

61 Table 2. 
In Table 2 is reflected the abandonment of children by municipalities, where Pristina is presented with the largest number of abandoned children for 2017.

Whereas, new cases of children who for other reasons have remained without parental care and family, as reported by the CSCs, are 131 children.

Children without parental care at the end of 2017, who are practically carried in 2018, are 696 children, of which:

- Foster care with relatives.

.551 children;

- Alternative foster care. .55 children;

- Sheltering within SOS Village (Dielli I, II, III) .13 children;

- Foster care in a SOS Family. 44 children;

- Sheltering within SDSF “Shtëpi dhe Shpresë për Fëmijët” 11 children;

- Sheltering within "Caritas Umbria”. 17 children;

- Children's home in Shtime. 3 children;

- OGC/UCCK .2 children; .696 children. ${ }^{62}$

\subsection{ADOPTION}

Through adoption, ${ }^{63}$ the child is placed under the custody of the person who wants to take the child under his / her care and responsibility. According to the provisions of the FLK, the adoption procedure is an exclusive competence of the court. Consequently, Article 180 paragraph 1 of the FLK stipulates that adoption shall be instituted before the court upon the request of adoptive parents. ${ }^{64}$ During developing this procedure, the court requests assistance from the custodian body. The court and custodian body are responsible for data and privacy security of the information collected during the adoption procedure. The decision shall be submitted only to the parties participating in the proceedings. Spouses may adopt the child only jointly. ${ }^{65}$ However, in exceptional cases, only one of the spouses may adopt the child when the other spouse is unable to act or has not reached the age of $21 .{ }^{66}$ Adoption is not established until the adoptive parent takes care of the child for a reasonable time determined by the court

62 The data are provided by the January - December 2017 annual work report of the Division for Social Services - Department of Social and Family Services, Ministry of Labour and Social Welfare.

63 Family Law of Kosovo, Law no. 2004/32, Article 167.

64 Family Law of Kosovo, Law no. 2004/32, Article 180.

65 FLK, Article 164, paragraph 1.

66 FLK, Article 165 paragraph 2. 
but not more than three months as a probationary period ${ }^{67}$. For adoption, the consent of the child ${ }^{68}$ and the consent of its parents must be taken. ${ }^{69}$

Undoubtedly, the importance of the institute of adoption and legal relationships between adoptive and adopted persons is of importance in defining the rights and responsibilities of parents and children. Historically, there has been a distinction in favour of the importance of blood links on the part of the father, ${ }^{70}$ to eliminate discrimination between extra-marital children, adopted children and children born in a wedlock.

According to FLK, only children can be adopted, and the persons who wish to adopt children must have reached the age of 21, i.e. one spouse must have reached the age of 25 and the other must be at least 21 years old.

Following, in a table are presented the statistics of adopted children over the years, according to the CSW in Pristina: ${ }^{71}$

\begin{tabular}{|l|l|}
\hline 2006 & 7 \\
\hline 2007 & 6 \\
\hline 2008 & 9 \\
\hline 2009 & 12 \\
\hline 2010 & 8 \\
\hline 2011 & 4 \\
\hline 2012 & 10 \\
\hline 2013 & 4 \\
\hline 2014 & 5 \\
\hline 2015 & 2 \\
\hline 2016 & 6 \\
\hline 2017 & 5 \\
\hline
\end{tabular}

As it can be seen from this table for the period 2006 - 2017, the largest number of children adopted in Pristina was in 2009, when 12 children were adopted, and the smallest number of adopted children was in 2015, with only 2 adoptions.

Adoption as a way of permanent protection of abandoned children without parental care is offered to potential children for local and international adoption. Requests for adoption are submitted to the Panel on the Placement of Children in Foster Care and Adoption, which is a professional body, composed of representatives from CSWs and partner NGOs, who should always consider the highest interest of children. The competent court makes the final decision on adoption.

\footnotetext{
67 FLK, Article 166 paragraph 1.

68 FLK, Article 168, paragraph 1.

69 FLK, Article 169, paragraph 1.

70 A. Mandro, E drejta Familjare, Tirana, 2009, p. 368.

71 Archive of the CSW in Prishtina, February 2018, Statistics collected by the CSW in Prishtina.
} 
Thus, based on the reports of the competent bodies, in 2017, the professional panel has received and reviewed requirements for placement of children in adoption, including requests from Kosovo CSWs, requests from the Basic Courts and requests from the International Foreign Authorities and that:

a) local adoption, 21 cases approved;

b) international adoption, 1 case of abandoned child approved, and 1 case of child without parental care approved for adoption to relatives.

As seen in total there have been 23 cases of approved adoptions during 2017 throughout Kosovo. $^{72}$

Establishing adoption creates effects on children. The adopted child acquires the legal status of a joint child of the spouses. After the adoption, the legal relationship between the child and its predecessors and cousins is terminated along with the rights and obligations arising therefrom. The child receives the surname of the adoptive person. Adopting creates family relationships between the adopters and their family on the one hand, and between the adopted and its successors on the other, with all rights and obligations. Likewise, after adopting, it is not allowed to prove the motherhood or paternity of the adopted child. With the establishment of adoption, the rights and obligations of the adopted person to his parents and other persons in the family are extinguished, as well as the rights and obligations of parents and family towards him.

\section{CONCLUSIONS AND RECOMMENDATIONS}

The paper as such, with its findings and recommendations aims to highlight the current developments in the drafting of legislation in Kosovo regarding children's rights. These rights, even before these changes and additions, have largely been in harmony with the Convention on the Rights of the Child and other international documents as they are relatively new laws, but there was a need for their modernization and incorporation of some more articles and chapters such as the Juvenile Justice Code.

Even though the drafting and development of legislation in Kosovo has not been easy considering the political, economic and social transition that Kosovo society has passed since the post-war (1999) until the consolidation of state institutions and mechanisms, no doubt, much has been done in this regard and now almost all international reports praise Kosovo's legislation, but point out the lack of its practical implementation.

Despite these difficulties, institutions within the mandate and competencies have been committed to ensure that the entire framework and content of legislation is always consistent and in harmony with the highest international standards.

The incorporation of new concepts and institutes within the child protection system is a very powerful indicator of reforming legislation and empowering children's rights.

72 Statistical data is provided by the January - December 2017 Annual Report of the Division for Social Services - Department of Social and Family Services, Ministry of Labour and Social Welfare. 
In this regard, it is worth emphasizing the strengthening and advancement at the level of mandatory implementation of the main principles of child protection, such as the principle of the best interest of the child, the principle of non-discrimination, the principle of free expression, the principle of the right to life and security, and other important principles.

In this regard, it is worth mentioning the establishment of the Probation Service, the designation of alternative measures and sentences as an alternative to prison and other punitive measures, mediation, the creation of a base for a friendly justice to children, the specialization of professionals and the creation of functions and positions throughout the justice system for children, where only the cases of children in contact with the justice system will be addressed. In this regard, good job has been done, but there is still a lot of work to be done by state mechanisms.

There has been a success so far in legislation reforming and capacity building for its implementation in practice, but challenges and difficulties have still been identified, which must be addressed to advance and implement this legislation.

This paper, however, is a reflection that reveals the work done so far and is a very detailed guide that will serve the future work to be done, so that the legislation on children's rights is further advanced, to reach the highest standards and to be in full harmony with international acts.

Even though one of the main conclusions in all international reports was that the legislation of the Republic of Kosovo in justice for children is largely in accord with the Convention on the Rights of the Child, yet the numerous analyses offered have been a strong basis for furthering this legislation. Thus, it is believed that some of the recommendations that are listed, and all that is said in this paper, best reflects on proposed reforms in legislation that relate to the principle of best interest, shortening the timeframes and procedural sensitivity, guaranteeing services and effective protection, as well as social, educational and health policies.

The drafting and implementation of legislation is a prerequisite for better protection of children's rights, but its drafting does not necessarily guarantees the effective protection of these rights. Child rights would be ensured and protected if there would be an increased political commitment of all institutions, an adequate budget allocation, increased human resources and the provision of better protection services, and at the same time the practical implementation of these laws.

\section{LITERATURE}

\section{SCIENTIFIC LITERATURE (BOOKS AND SCIENTIFIC PAPERS)}

1. Bahtiri, B.; Qerimi, I., "Family and Marriage in the Family Act of Kosovo", JOR - Jahrbuch für Ostrecht 2017/2, 307-327, Germany.

2. Bahtiri, B.; Qerimi, I., "Mediation as a Way of Alternative Resolution of Disputes in Kosovo", Iliria International Review, 2014, 1, 291-322, Kosovo. 
3. Bahtiri, B.; Qerimi, I., "Vermittlung und Versöhnung als alte Phänomene unter Albanern (Mediation and reconciliation as an old phenomenon amongst Albanians), Die Wirtschaftsmediation-Fachmagzin für Unternehmen und öffentliche Verwaltung", 2014, 4, 56-60, Germany.

4. Bilalli, A.; Bahtiri, B., "E drejta Romake", Pristina, 2015.

5. Ed. by K. Heilbrun, N. E. Sevin Goldstein, and R. E. Redding, Juvenile Delinquency, Prevention, Assessment and Intervention, Oxford University Press, 2005.

6. Fionda, J., Devils and Angels - Youth Policy and Crime, Law School Southampton University, Hart Publishing Oxford and Portland, Oregon, 2006.

7. Halili, R., Viktimologjia, Pristine, 2011.

8. Junger Tas J.; Dünkel F., Reforming Juvenile Justice, Springer, 2009.

9. Mandro, A., „E Drejta Familjare“, Tirana, 2009.

10. Podvorica, H., "E Drejta Familjare”, Pristina, 2011.

11. Qerimi, I.; Bahtiri, B., „Alternative Sanktionen im kosovarischen Strafrechtssystem, Zeitschrift für die gesamte Strafrechtswissenschaft“, Vol. 128, Issue 4 May 2017, 1207-1226, Germany.

12. Qerimi, I., „Gewohnheitsrecht in Albanien: Rolle und Herkunft des Kanun. Uberblick uber den Kanun bei den Albanern. 2. bearbeitete und vervollstandigte Auflage”, Munich, 2010.

13. Salihu, I., E Drejta Penale - Pjesa e Posaçme, Kolegji Fama, Pristine, 2014.

14. Sahiti, E., Psikologjia gjyqësore, Pristine, 2007.

15. Sahiti, E.; Murati, R., E Dejta e Procedurës Penale, Botime Artini, Pristine, 2016.

\section{LEGAL ACTS}

1. Constitution of the Republic of Kosovo, 2008.

2. United Nations Convention on the Rights of the Child, adopted on 20 November 1989 at the 44th Session of the United Nations General Assembly in New York and entered into force on 2 September 1990.

3. Optional Protocol to the Convention on the Rights of the Child, dedicated to the sale of children, child prostitution and child pornography 28 March 2007.

4. Kosovo Juvenile Justice Code No.03 / L-193 Official Gazette 78/2010.

5. Family Law of Kosovo (Law No. 2004/32) adopted by the Assembly of Kosovo in February 2006, and was promulgated by the Special Representative of the Secretary-General with UNMIK / REG / 2006/7.

6. Law on Marriage and Family Relations, Official Gazette of SAPK no. 10/84, dated March 28, 1984.

7. Kosovo Law on Labour no. 03/L-212.

8. Law on Social and Family Services, Law no. 02/L-17.

9. Law of Albania No. 18/2017 on the rights and protection of children.

10. Law No. 04/L-032 on pre-university education in the Republic of Kosovo.

11. Juvenile Justice Code 2018. 


\section{STUDIES, STATISTICAL DATA AND OTHER SOURCES}

1. European Centre for Parliamentary Research and Documentation: Request 407 - Violence against children, by the National Assembly of the Republic of Serbia, Request 866 BillonYouth (Children), by Slovak National Council).

2. Legal Framework for Children's Rights in Kosovo: Study on Compliance of Legislation in Force with the Convention on the Rights of the Child / UNICEF, Pristina, 2014.

3. Children's Rights in the Juvenile Justice System, Progress Reports for Kosovo, 2014.

4. Judgment of the District Court in Gjilan, P. No. 97/65.

5. Statistical data provided by the January - December 2017 Annual Report of the Social Services Division - Department of Social and Family Services, Ministry of Labour and Social Welfare.

6. Statistical data provided by Vebi Mujku, Director of the Centre for Social Work in Pristina, 26. 2. 2018. 


\section{PRAVNI ASPEKTI REGULIRANJA I ZAŠTITE PRAVA DJECE NA KOSOVU}

\section{Sažetak}

Djeca su najosjetljiviji dio obitelji, važni i za budućnost obitelji i za društvo u cjelini. Stoga država ima obvezu upotrijebiti sve raspoložive mehanizme i pobrinuti se za stvaranje uvjeta za njihov odgoj i dobrobit u najboljem interesu djeteta.

Na Kosovu djeca i mladi čine 60\% populacije. Važno je stoga ulagati u zaštitu i promicanje njihovih prava bez obzira na to jesu li u sukobu ili u kontaktu sa zakonom. U tom smislu, nužna je reforma i harmonizacija zakonodavstva u skladu s najboljim međunarodnim standardima, što se trenutačno i provodi na Kosovu.

Ključne riječi: $\quad$ djeca, obitelj, zaštita, maloljetničko pravosuđe, alternativne mjere i raznolikost, minimalna dob kaznene odgovornosti za djecu, djeca kao žrtve i svjedoci

\section{(c) (1) (9)}

This work is licensed under a Creative Commons

Attribution-NonCommercial 4.0 International License.

\footnotetext{
* Dr. sc. Bedri Bahtiri, docent, Pravni fakultet Sveučilišta u Prištini, Priština, Republika Kosovo. Adresa e-pošte: bedri.bahtiri@ uni-pr.edu. ORCID: https://orcid.org/0000-0002-8216-808X.

** Dr. sc. Islam Querimi, docent, Sveučilište u Mitrovici "Isa Boletini", 40000 Mitrovica, Republika Kosovo. Adresa e-pošte: i-qerimi@hotmail.com. ORCID: https://orcid.org/0000-0002-1645-079X.
} 